\title{
Metrology of morphological response of Siberian elm to drought stress: increased stomatal pore depth
}

\author{
Ki Woo Kim", Go Eun Park², Don Koo Lee² \\ From IUFRO Tree Biotechnology Conference 2011: From Genomes to Integration and Delivery \\ Arraial d Ajuda, Bahia, Brazil. 26 June - 2 July 2011
}

\section{Background}

Structural characteristics of stomata consist of stomatal shape, density, depth, and pore dimension. Commonly called Siberian elm, the species Ulmus pumila L. is a fast-growing and small to medium-sized tree. Due to the superb adaptations to the harsh conditions of the Gobi Desert, the trees have been preferentially planted in Mongolia. It is worthwhile to investigate the morphological characteristics of the tree species that are tolerant to drought stresses in such arid areas.

\section{Materials and methods}

Based on average annual precipitations, two types of leaf specimens were collected from Korea, China, and Mongolia: (i) leaves under normal environmental conditions and (ii) leaves under arid conditions. Leaf stomatal characteristics of Siberian elm were investigated by electron microscopy and white light scanning interferometry [1].

\section{Results and conclusions}

Field emission scanning electron microscopy revealed stomata on the lower leaf surface of the tree species. Measured as ca. 30 micrometers in width, the stomata appeared to be oval in shape. In-lens secondary electron imaging by a coaxial annular type detector showed a difference in depth from epidermis to pore between the two types of leaves. Leaf stomata under arid conditions appeared to have higher levels of depth from epidermis to pore than ones under normal conditions (Figure 1). Line profile analysis by white light scanning interfero-
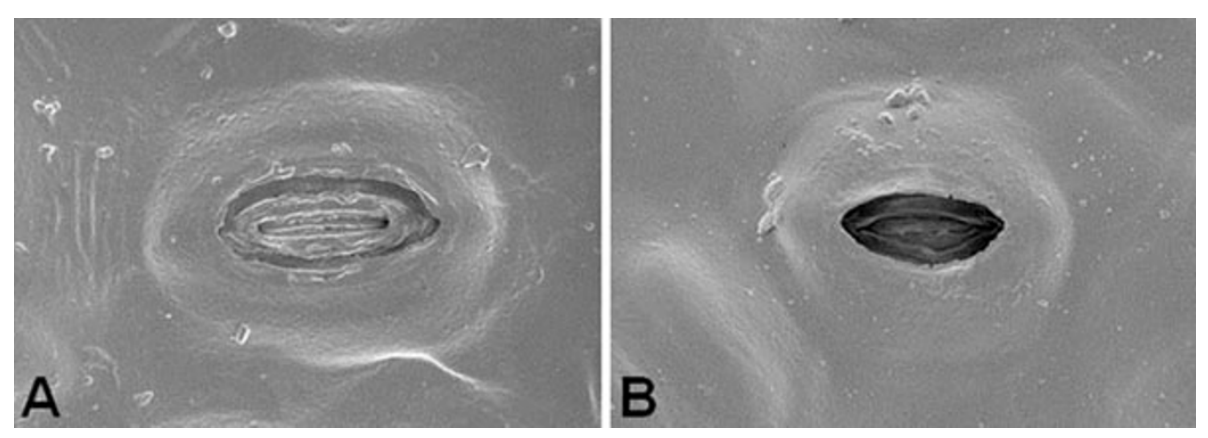

Figure 1 Field emission scanning electron micrograhs of stomata of Siberian elm. (A) Stoma under normal conditions. (B) Stoma under arid conditions.

\footnotetext{
* Correspondence: kiwoo@knu.ac.kr

${ }^{1}$ School of Ecological and Environmental System, Kyungpook National

University, Sangju, 742-711, Korea

Full list of author information is available at the end of the article
}

(c) 2011 Kim et al; licensee BioMed Central Ltd. This is an open access article distributed under the terms of the Creative Commons 


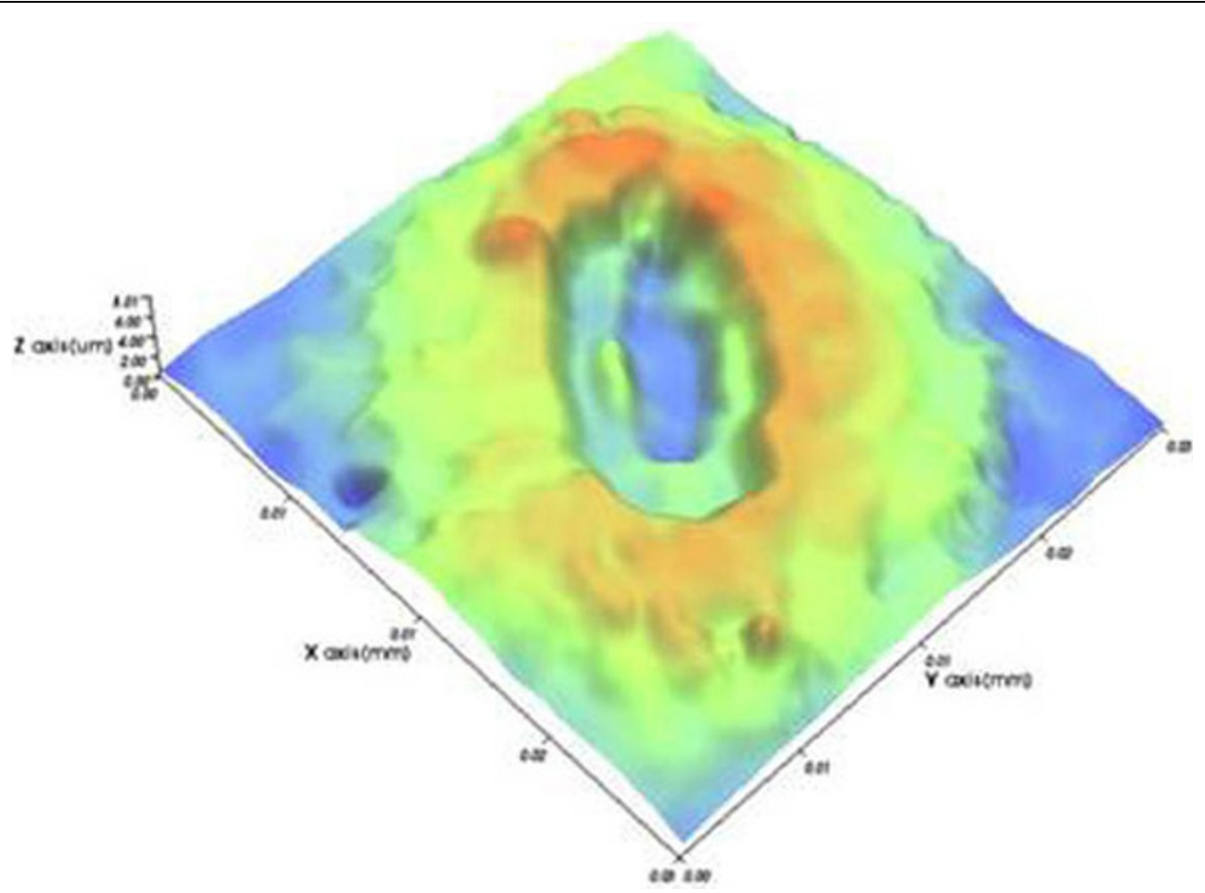

Figure 2 Three-dimensional surface plot of a stoma under arid conditions by white light scanning interferometry.

metry allowed for the nondestructive measurement of the stomatal dimension (Figure 2). The depth from epidermis to pore of stomatal complexes under normal conditions was ca. $1.79 \pm 0.13$ micrometers, whereas that under arid conditions was ca. $2.12 \pm 0.08$ micrometers. In addition, higher levels of surface roughness were observed in stomata under arid conditions than those under normal conditions. These results suggest that increased stomatal pore depth would be responsible for the adaptations of the tree species to arid conditions. Furthermore, such architectural differences in stomatal dimension could be quantitatively analyzed by complementary microscopy.

\section{Author details}

${ }^{1}$ School of Ecological and Environmental System, Kyungpook National University, Sangju, 742-711, Korea. ${ }^{2}$ Department of Forest Environmental Science, Seoul National University, Seoul, 151-742, Korea.

Published: 13 September 2011

\section{Reference}

1. Kim KW, Lee IJ, Kim CS, Lee DK, Park EW: Micromorphology of epicuticular waxes and epistomatal chambers of pine species by electron microscopy and white light scanning interferometry. Microsc Microanal 2011, 17:118-124.

doi:10.1186/1753-6561-5-S7-P90

Cite this article as: Kim et al:: Metrology of morphological response of Siberian elm to drought stress: increased stomatal pore depth. BMC Proceedings 2011 5(Suppl 7):P90.

\section{Submit your next manuscript to BioMed Central} and take full advantage of:

- Convenient online submission

- Thorough peer review

- No space constraints or color figure charges

- Immediate publication on acceptance

- Inclusion in PubMed, CAS, Scopus and Google Scholar

- Research which is freely available for redistribution 